УДК $141.3+165.62$

DOI 10.35423/2078-8142.2020.1.2.05

A. В. Ільӥна, кандидат мистецтвознавства, докторантка Інституту філософії імені Г. С. Сковороди НАН Украӥни м. Київ, Украӥна e-mail: husserliana2016@ukr.net ORCID: http://orcid.org/0000-0003-4921-5777

\title{
АВТО-РЕФЕРЕНТНІСТЬ І АВТО-АФЕКЦЙНІСТЬ ЯК АЛЬТЕРНАТИВНІ МОДЕЛІ ПРОЧИТАННЯ ДЕКАРТОВОЇ КОНЦЕПЦІЇ СОGITO: ТРАНСЦЕНДЕНТАЛЬНО-ФЕНОМЕНОЛОГІЧНИЙ КОНТЕКСТ
}

Статтю присвячено дослідженню альтернативних можливостей інтерпретаиії Декартової концепиії cogito: як автореферентної структури $i$ як авто-афекційності. Контекстом аналізу виступає трансиендентально-феноменологічний ракурс погляду на картезіанську філософію як на засновок трансцендентального мотиву. Визначено роль принципу авто-референтності в трансиендентальному дискурсі. На трунті розгляду перспектив тлумачення картезіанського підходу, запропонованих М. Анрі й Ж.-Л. Марйоном, виявлено моменти іррелевантності автоафекиійної настанови вимогам трансиендентального мислення $i$ втомивовано адекватність авто-референтної моделі його засадам. Авторка доходить висновку, щзо, попри позірну пріоритетність авто-афекиійності для трансиендентального дискурсу, пов'язану насамперед з притаманною їи радикалізацією функиіонального аспекту свідомості й усуненням небезпеки субстантиваиіï cogito, закладеної в структурі авто-референтності, остання видається відповіднішою вимогам трансиендентального мислення, оскільки передбачає збереження принципу відношення-відмінності, конститутивного для трансиендентальної думки - який в умовах авто-афекиійності виявляється редукованим.

(C) Ільїна А. В., 2020 
Ключові слова: авто-референтність, авто-афекиійність, cogito, феноменологія, інше.

Серед множини теоретичних винаходів картезіанської філоcoфiï, концепція cogito [10] посідає особливе місце, позначаючи собою початок нової філософської парадигми: «епохи суб’єкта». Власне, Декартове cogito лежить в основі трансцендентальної концепції суб'єктивності (свідомості). У сучасній філософії - тобто, філософії «після модерну», намагання підважити та-або радикально переосмислити ідею і статус суб'єкта (намагання, які частогусто виявляються не так делегітимиацією трансцендентальної настанови, як іiі своєрідною радикалізацією) більш чи менш експліцитно, але 3 необхідністю впираються в закладені Декартом засади філософського тлумачення суб'єктивності. Актуалізація Декарта в умовах філософії сьогодення значною мірою пов'язана 3 поворотом в декартознавстві, здійсненим видатним французьким феноменологом - Жан-Люком Марйоном, який в радикально своєрідний спосіб продовжує класичну феноменологічну лінію реінтерпретації й ре-актуалізації Декарта, що червоною ниткою проходить крізь тексти засновника феноменології - Едмунда Гусерля.

Показово, що переосмислення Декарта відбувається синхронно 3 його «трансценденталізацією» (і значною мірою завдяки ій): Гусерль експліцитно визначає власний проект як трансцендентальний, апелюючи до картезіанської думки як до джерела «трансцендентального мотиву»; в Марйоновому тлумаченні Декарта одним 3 визначальних сюжетів $є$ трансцендентальні аспекти картезіанського мислення.

Альтернатива авто-референтності й авто-афекційності - точніше, проблема вибору релевантної стратегії тлумачення картезіанської концепції з означених альтернатив - стосується саме базової теми Декартового філософування: теми ego cogito. Ця проблема оприявнюється в річищі i на грунті трансцендентальнофеноменологічних інтерпретацій Декарта та, артикулюючи трансцендентальні моменти картезіанського підходу, інтенсифікується насамперед в межах таких інтерпретаційних стратегій, що пов'язані зі спробами радикального переосмислення Декартового спадку в умовах сучасних філософських пошуків і запитів. Таким 70

H.Skovoroda Institute of Philosophy of the NAS of Ukraine 
чином виявляється вмотивованою актуальність поставленого на трансцендентальних засадах питання про авто-афекційність або авто-референтність cogito в картезіанській концепції.

Метою цієї статті $є$ критичне дослідження можливостей і наслідків інтерпретації картезіанської концепції в річищі ідеї автоафекційності - порівняно з перспективою тлумачення Декартового cogito на засадах принципу авто-референтності - в контексті трансценденталістського позиціонування філософії Декарта. Досягнення даної мети вимагає виконання наступних завдань: показати значення принципу авто-референтності для трансцендентального дискурсу в цілому; в рамках дискурсивного поля трансцендентальної настанови, порівняти принципи авто-референтності й автоафекційності; проаналізувати спроби витлумачення картезіанської концепції в річищі проблеми авто-афекційності; на грунті тлумачень картезіанської проблематики, визначити моменти релевантності або іррелевантності авто-афекційної і, відповідно, автореферентної настанов вимогам трансцендентального мислення.

Проблема авто-референтності в зв'язку з Декартовою філософією викликає інтерес багатьох дослідників. Так, Клаус Біркман розглядає іï в контексті дослідження Гегелевого погляду на декартівську концепцію cogito. Він акцентує момент непростоти останнього, підкреслює, що певність (certitude) як фундаментальне домагання картезіанської думки досягається саме завдяки автореферентності Я, а також використовує феноменологічну термінологію для пояснення стосунку між різними вимірами Я в автореферентному акті ідентифікації ноематичного $Я$, про яке Я мислить, і Я ноетичного, що власне здійснює акт мислення [8, с. 651]. Етьєн Балібар порівнює авто-референтність картезіанського еgо 3 авто-референтністю, що має місце в теологічному дискурсі: притаманною засадничій біблійній фразі «я є той, хто я є» [5, с. 102-103]. Вільям Бус розглядає авто-референтність cogito в річищі логічної проблематики [7].

Цікавий аналіз авто-референтності, на якій грунтується теза «я $є$ я» («je suis moi») - численні тематизації й інтерпретації якої в модерній і після модерній філософії значною мірою завдячують картезіанській ідеї cogito як своєму джерелу й певному інваріанту концептуалізацій - здійснює Едгар Морен. Дослідник засвідчує, 
що «авто-референція є спроможністю не лише до самопосилання, а й до посилання на себе по відношенню до зовнішнього світу, в центрі якого ми розташовані» [21, с. 6]. Відповідно, таким чином зрозуміла авто-референтність перекривається 3 проблемою фінітності суб'єкта («можна сказати, що... суб'єкт стає власною фінітністю, оскільки встановлює свою само-трансцендентність» $[21$, с. 6]) і його стосунку до іншого. Даний ракурс тематизації cogito, який Морен не прив'язує до Декарта буквально, лежить в основі тлумачення картезіанської позиції Марйоном і містить мотиви, що зумовлюють і уможливлюють трансценденталістське прочитання концепції Декарта: відношення до іншого і проблема фінітногоінфінітного.

Стівен Хетерінгтон, розглядаючи інтерпретацію картезіанського cogito Пітером Слезаком (Peter Slezak), відзначає, що в іiі основі лежить «комбінація авто-референції і заперечення» [14, с. 85]. Важливість такого мисленнєвого ходу полягає в тому, що він поєднує проблему авто-референції з таким фундаментальним аспектом Декартової концепції, як принцип сумніву, що, своєю чергою, $\epsilon$ важливим засновком конституювання трансцендентальнофеноменологічного принципу епохе.

Проблема авто-афекційності щодо декартівської концепції насамперед $є$ предметом уваги видатних феноменологів Мішеля Анрі й Жан-Люка Марйона (останній також є визначним декартознавцем): аналіз підходів цих філософів лежить в основі даної розвідки, тому зараз ми не зупинятимемося детальніше на їхніх тезах. Ініційована концепцією Анрі, тема авто-афектації cogito як своєрідної альтернативи класичному для феноменології інтенційному тлумаченню свідомості має резонанс у подальших феноменологічних дослідженнях. Наприклад, Джеймс Харт звертає увагу на протиставлення, що виникає між гайдегерівським і анрієвским прочитаннями Декартової концепції на грунті розрізнення, відповідно, авто-референтного й авто-афекційного підходів. Він покликається на пасаж самого Анрі, в якому філософ протиставляє Гайдегеровому розумінню еgо як апріорної складової поля, що відкривається явленням і в якому здійснюється будь-яке феноменологічне «відкриття» - поля, структура якого є ідентичною ретро-референції [27] 
(до) еgо - ідею афекційної іманентності, яка, на його думку, власне і відповідає Декартовому підходу (М. Анрі, «Генеалогія психоаналізу»: цит. за [11, с. 81]).

Едуард Мель, аналізуючи інтерпретацію Анрі декартівської концепції, яка постає однією з версій «феноменологізації» останньої, пише, що «авто-афектація є сутнісною структурою картезіанського cogitatio» [20, с. 32] і досліджує питання, зокрема, чи насправді «авто-афектація описує структуру cogitatio замість інтенційності» [20, с. 32]. У контексті даної розвідки (який буде прояснений в ході основної частини дослідження) важливо звернути увагу на те, що авто-афекційність таким чином приписується акту (cogitatio), а не інстанції продукування актів (cogito): тобто, автоафекційність є властивістю чистої функціональності свідомості поза будь-якою іiі субстантивацією та-або предметним озмістовленням. Водночас, cogito, будучи по-трансценденталістськи функціональним, разом з тим (1) постає, у феноменологічних термінах, умовою можливості актів свідомості (що значною мірою робить декартівську концепцію релевантною трансцендентальнофеноменологічним преференціям) і (2) тяжіє до субстантивації (що, власне, постає найпершою підставою трансцендентальнофеноменологічної критики Декарта).

Не зважаючи на те, що теми авто-референтності і автоафекційності в стосунку до картезіанської філософії є вагомими і досить поширеними сюжетами досліджень, залишаються без відповіді або взагалі не поставленими певні важливі питання, які однак видаються необхідними складовими означеної проблематики. У даній статті порушуються наступні з таких питань, що зумовлює ii дослідницьку новизну: 1) відмінність між принципами автореферентності й авто-афекційності в контексті трансцендентальної проблематики взагалі і в стосунку питання картезіанського трансценденталізму, зокрема; 2) відповідність авто-референтності й авто-афекційності вимогам трансцендентального дискурсу; 3) доцільність оприявнення авто-референтних (і авто-афекційних) аспектів Декартової концепції cogito в контексті її «трансценденталізації» [28].

Авто-референтність належить до низки базових характеристик трансцендентального мислення [2, с. 131]. Вона притаманна 
трансцендентальному дискурсу 3 огляду на його фундаментальну зумовленість проблемами дослідження власних засад, спроможностей, меж і т.д. Авто-референтність є ефектом і методом, який відповідає щонайменше трьом засадничим параметрам трансцендентальної настанови: 1) згідно з особливостями «трансцендентального зсуву» - замість виходу на зовнішнє (об’єктне) мислиме має місце повернення назад до суб'єкта/мислення/свідомості/письма (вибір 3 цих варіантів специфікується відповідно до типу трансцендентального дискурсу; 2) при цьому зберігається і навіть радикалізується аспект відношення (за браком зовнішнього об'єкта, увагу зосереджено саме на проблемі само-відношення); 3) автореферентність найпершим чином реалізується в модусі самокритичності, що постає як радикалізація і гіперболізація властивої трансценденталізму критичної настанови.

Етьєн Балібар наголошує на фундаментальному значенні властивості авто-референтності для трансцендентальної свідомості. Він стверджує, що критична аргументація Канта проти раціональної психології Декарта не полягає у виявленні невірної автореференції в картезіанському дискурсі (що грунтується на хибному переході від «я мислю, що...» як універсальній формі вираження свідомості чогось до «я» як об'єкту пізнання ««quelque chose» de connaissable» [6, c. 24]) - або принаймні не обмежується цим. Адже сам Кант і саме в своєму критичному міркуванні апелює до автореферентності Я [29]. Хибним кроком відтак виявляється не автореферентність Я як така, а його субстантивація (уречевлення, об'єктизація і т.п.) [30].

Цікавий зв'язок виникає між поняттями авто-референтності і авто-афектації. Леонар Лоулор фактично ототожнює їх у процесі і в контексті аналізу критики Дерида, спрямованої на гусерлівську концепцію феноменологічної суб'єктивності [31]. Лоулор синонімує авто-афікування і самовідношення, розглядаючи як приклад авто-афектації арістотелівське визначення Бога як «думки, що мислить себе», а також апелюючи до деридианського визначення автобіографії як форми авто-афікування [18].

Утім, вважаємо за важливе провести розрізнення між автоафекційністю і авто-референтністю, що яскраво оприявнюється 
саме на грунті деридианської критики феноменології Гусерля. Щонайменше першу видається можливим розглядати як окремий випадок другої, причому своєрідний - i, отже, не надто репрезентативний і навіть такий, що не повністю відтворює властивості взірцевого інваріанту. Адже афікування належить виміру чуттєвості і в силу своєї дорефлексивності забезпечує первинну цілісність суб'єкта, коли йдеться про його самоспрямованість і самозастосовність (self-application). Саме таку «некритичну» єдність, самодоступність і самоочевидість феноменологічного суб'єкта викриває Дерида в гусерлівській концепції (або, принаймні, приписує їй зазначені проедикати). Натомість авто-референтність $\epsilon$, навпаки, джерелом (і навіть засобом) деконструкції псевдо-ідентичності на грунті своєрідного розщеплення тотожності суб'єкту, концепту і т.д., подвоєння, в результаті якого утворюються порядково відмінні ітерації: вихідне дещо виступає і як певна дія (операція), і як ії об’єкт. Тобто, в певному аспекті - за певною функцією - автореференція збігається з тим, що Дерида називає гетеро-афектацією, пов'язаною 3 неуникненним «просотуванням» іншості в іманентність феноменологічної свідомості [32].

На грунті Декартової концепції виявляється не лише нетотожність авто-референтності й авто-афекційності, але навіть певна альтернативність цих принципів, прийняття до уваги якої видається важливим у контексті дослідження трансцендентального дискурсу взагалі й феноменологічної філософії, зокрема.

Щодо картезіанської філософії проблема авто-референтності, яка загалом є вельми значущою для трансцендентального дискурсу, набуває особливої вагомості. Адже авто-референтність $є$ властивою функціонуванню і тематизації cogito - ключового принципу Декартової концепції, котрий чимало дослідників небезпідставно оцінюють як перформатив [33; 34].

Проблематичність i, водночас, очевидність автоpeферентності cogito є темою нескінченних глибоких досліджень. Важливо відзначити, що актуальність (а можливо і саму постановку) цьому питанню надає феноменологічний дискурс.

Як ми вже відзначали, авто-референтність належить до засадничих характеристик трансцендентального мислення. Принцип авто-референтності видається вдалим поєднанням квазі- 
передування, квазі-ієрархічності (оскільки йдеться про конституювання порядків різних ступенів) і квазі-простоти (оскільки властива авто-референтності відмінність є тільки синтаксичною), з одного боку, і нередуковної відмінності - i, відповідно, відношення, - 3 іншого. Отже, авто-референтність, зберігаючи (хоча й у деконструйованому вигляді) обидва протилежні i, здавалося б, взаємовиключні налаштування, відповідає трансцендентальному прагненню до пов'язавання радикально відмінних порядків, принципів, концептів тощо. Тож, «утримуючись» від конкретного, «сюжетного» іншого, авто-референтність разом із тим позначена інакшістю. Поєднання цих двох факторів робить авто-референтність трансцендентальним конструктом par excellence, котрий, визначає своєрідну інакшість als ob, nро яку і до якої у випадку самоспрямування здійснюється інтенційна квазі-референція трансцендентальнофеноменологічної свідомості.

Говорячи про іншість у контексті картезіанського дискурсу ми найпершим чином апелюємо до ідеї екстеріорного. Цю настанову значною мірою радикалізує феноменологія (особливо у версіях Левінаса, Марйона, Дерида i, дещо в іншому аспекті, Вальденфельса). Мішель Анрі у такий спосіб характеризує феноменологічний підхід, який він критикує в річищі власної концепції радикальної іманентності: «Необхідна референція свідомості до чогось іншого повинна бути зрозуміла: це референція до самої інакшості [à l'altérité elle-même]. Рух cogito до зовнішнього первинно не є рухом до сущого, це рух до зовнішнього як такого, до чистої екстріорності... свідомість мислиться як така, що здійснюється лише на шляху до зовні щодо себе, тобто, фактично, у і через екстеріорність» [12, с. 261]. Можна уточнити, що іншість, яку привносить автореферентність [35], є іншістю не лише екстеріорного взагалі, але також й іншістю об'єкта по відношенню до суб'єкта - на відміну від нього.

При цьому певне подвоєння, розщеплення картезіанського суб'єкта (визначаємо ми його як трансцендентальний чи ні), що передбачається авто-референтністю, є підставою як трансценденталістської критики Канта і Гусерля на адресу Декарта (адже наслідком авто-референтного розщеплення є субстантивація cogito), 
так і радикально-феноменологічної критики критичного трансценденталізму Канта i «класичної» феноменології гусерлівського кшталту з боку Сартра і Анрі (про концепцію якого докладніше йтиметься далі). Ця остання критика закидає трансцендентальному еgo (Сартр) або феноменологічній свідомості (Анрі) момент внутрішньої відмінності, подвоєння і розрізнення, що так чи інакше позбавляє свідомість феноменологічної своєрідності й чистоти, через об'єктивацію, перетворення на частину світу «природної настанови» і т.д. [36].

Дистинкція між авто-референтністю і авто-афекційністю нерідко стирається дослідниками - що може призводити до нівелювання особливостей кожної з двох операцій [37]. Натомість їхня відмінність, крім названого вище аспекту обмеженості автоафікування чуттєвим виміром, полягає в тому, що автореферентність грунтується на відмінності та іншості і передбачає момент als ob-екстеріорності, тоді як авто-афекційність утримується в царині іманентності. Але, водночас, хотілося б наголосити на спільності, що дає можливість у певних аспектах і контекстах розглядати авто-афектацію як окремий випадок авто-референції. Така амбівалентність визначає специфіку рефлексій на тему кожного 3 цих понять: їхнє ототожнення приховує фундаментальні риси відмінності, що за інших обставин виходять на яв; але при цьому їхнє протиставлення обмежується (і при цьому зумовлюється) засадничою подібністю, на основі якої, власне, і проявляються моменти розрізнення між авто-референтністю і авто-афекційністю.

Класичний випадок артикулювання теми авто-афектації в трансцендентальному дискурсі становить і1і кантівська тематизація в контексті обговорення теми внутрішнього чуття. Кант проводить аналогію між порядком зовнішнього чуття в просторі і внутрішнього чуття - в часі. Кожному з них відповідає свій тип афікування: відповідно, зовнішнього афікування і авто-афікування. При цьому Кант уточнює, що таким чином йдеться про самопізнання суб'єкта як явища, а не як такого, яким він $є$ сам-по-собі [17, с. 259]. Крім того, Кант говорить, що приклад авто-афектації надає нам будь-який акт уваги $[17$, с. 259]: цей нюанс перекидає міст до феноменологічного дискурсу, в якому і модус уваги, i принцип авто-референтності, і чинник авто-афектації (принаймні, 
згідно з деридианською інтерпретацією Гусерлевого підходу, викладеною в «Голосі й феномені») мають велику значущість.

Поняття авто-референтності і авто-афектації (автоафекційності) почасти змішують такі відомі дослідники феноменологічної філософії, як Леонард Лоулор і Домінік Жаніко, що однак не видається зовсім некоректним: адже, справді, обидві операції мають спільне підгрунтя, і ця загальність дає підстави і можливість розширити універсальну для трансцендентального дискурсу проблематику авто-референтності за рахунок питання авто-афектації. Згідно з дефініцією Лоулора, «авто-афектація трапляється, коли я афікую самого себе, коли афікування є тим самим, що й афіковане» [18].

Акцент на дієвості, властивий авто-афектації, позбавляє небажаної фази субстантивації, яка однак зберігається в межах процедури авто-референції: отже, здавалося б, саме авто-афекційність - а не авто-референтність - має втілювати трансцендентальну (особливо - феноменологічну) своєрідність свідомості, уникаючи декартівської помилки «шматочка світу». 3 огляду на один з аспектів авто-референтності, який дається взнаки, якщо ми позбавимо останню необхідного для трансцендентального дискурсу модусу квазі- або als ob - а саме, з огляду на об'єктність, що виникає в результаті розщеплення свідомості або суб'єкта [38] - феноменологічна свідомість (як удосконалений варіант ego cogito), здається, не може бути авто-референтною у звичайному сенсі: адже саме в позбавленні еgо статусу речі світу, його функціоналізації, полягає результат Кантово-Гусерлевої критики картезіанського ego cogito ergo sum. Отже, трансцендентально-феноменологічний зсув імплікує можливість трансформації авто-референтності в автоафекційність: можливість, яка в перспективі радикалізації феноменологічних засад може видаватися навіть необхідністю.

У своєму аналізі концепції Мішеля Анрі, Жаніко визначає авто-афекційну структуру іманентності як чисту авто-референцію [16, с. 73]: відтак авто-афекційність постає як своєрідний гіперболічний варіант авто-референтності. Засади такого перекривання (щоб не сказати - підпорядкування) знаходимо в тексті самого Анpi. Своє завдання від вбачає в оприявненні «сутності маніфестації», 
і з цією метою вдається до виявлення способу або способів «маніфестації сутності». Тематизуючи ідею авто-афекційності як чистої іманентності, що лежить в основі феноменологічного мислення i буття (для Анрі властивою є онтологізація феноменології), філософ стверджує, що «Онтологічна можливість маніфестації сутності полягає у зворотній референції [rétro-référence] сутності до самої себе», і що, при цьому, «явлення акту явлення віднаходить свою умову в самоявленні цього акта собі самому» [12, с. 289]. Коли Анpi, здавалося б, ототожнює авто- (ретро-)референцію і автоафектацію («авто-афектація означає ретро-референцію сутності маніфестації до самої себе» [12, с. 290]), йдеться про так би мовити «вироджений випадок» авто-референції, оскільки, позбавлена будь-якої щойності або теми, остання таким чином стосується чистої функціональності маніфестації.

До такого радикалізму, що має перевершувати звичайну референтність феноменології - зокрема й авто-референтність - шляхом «зсуву» до іманентності, має призводити радикалізація таких аспектів трансцендентального мислення, як мотив пошуку умов можливості і «деконструкція» об'єктності й субстанційності. «Вторгнення концепту авто-афектації у проблематику, що стосується сутності маніфестації, дедалі менше видається контингентним, коли рефлексія детальніше задається питанням про умови, які роблять цю сутність можливою, тобто, які ії визначають», - відзначає Анрі [12, с. 290]. Радикалізація акту - до якого, власне, зводиться сутність (відтак виявляючись несубстанційною, необ'єктною) і з яким вона ототожнюється (Анрі пише про «явлення акту явлення, тобто, сутності» [12, с. 289]; «зворотна референція акту явлення до самого себе $є$ тим, що визначає цей акт у його сутності» $[12$, с. 289]) також у принципі може розглядатися як гіпербола трансцендентального мотиву [39]. При цьому слід зважити на те, що Анрі не відмовляється від ідеї трансцендентального (що, зокрема, вмотивовує можливість критики його підходу з позицій трансценденталізму). Так, одним із його важливих винаходів є поняття «трансцендентальної афекційності» (так би мовити, модусом здійснення якої - якщо взагалі не синонімом - $\epsilon$ авто-афектація). «Авто-афектація не є порожнім або формальним поняттям,.. вона визначає феноменологічну реальність самого життя - реальність, 
чистою субстанційністю і чистою феноменальністю якої є трансцендентальна афекційність» [40; 13, с. 30-31].

Отже, Анрі у своєму радикалізмі «вдосконалює» гусерлівське «вдосконалення» Декарта, коли зазначає про авто-афекційність ego, про іманентну суб'єктивність - а це означає принципову необ'єктність і в принципі необ'єктивованість суб'єктної царини. Але в такій радикалізації вбачається одна серйозна небезпека: запропонована Анрі редукція інтенційності і разом 3 нею будь-якої квазі-об'єктності загрожує розривом із принципом відношеннявідмінності, який лежить в основі трансцендентальнофеноменологічного мислення - і отже, втратою досвідного стосунку до іншого [41].

Можна заперечити, що ми таким чином сплутуємо дві різні проблеми: перша стосується субстантивації свідомості, а друга відношення $з$ екстеріорним іншим. Перша потребує розв'язання (усунення) в межах трансцендентально-феноменологічної настанови, а друга становить необхідну вимогу останньої. Але для заперечення автономності й розділеності цих питань повернімося до картезіанської концепції, на грунті якої найбільш чітко виявляється позірність їхньої окремості.

По-перше, Декартовій концепції властива засаднича взаємозалежність свідомості й іншого, cogito й екстеріорного: зв'язок між ними, виявленню якого ми завдячуємо, насамперед, Марйоновій інтерпретації, оприявнюється на грунті ідеї інфінітного (ідеї Бога). I цей зв'язок у певних аспектах набуває ознак зумовлювання і перекривання (якщо взагалі не ототожнення за певними предикатами). Отже, радикальне розрізнення 1) способів позиціонування i 2) типів пізнавальних процедур у стосунку, відповідно, cogito i екстеріорного іншого не видається коректним: існує потреба в їх певній універсалізації. По-друге, Декартова очевидність ego cogito має слугувати патерном, взірцем мисленнєво-пізнавального акту, на основі i за зразком якого має вибудовуватися все інше (пі)знання - хоча у випадку cogito інше як «об'єкт» пізнання знаходиться в нульовій позиції. Тож, підваживши саму структуру, трансцендентальну синтаксичну модель можливого пізнання, якою є ego cogito (cogito, sum), ми тим самим ставимо під питання засад- 
ничі аспекти трансцендентального мислення, започаткованого картезіанською філософією.

Такий деструктивний наслідок спонукає переглянути положення про не-об'єктність у межах феноменологічнотрансцендентальної настанови. Адже специфікою трансцендентального (в тому числі - феноменологічного) підходу є позиція на межі між відмінностями, радикальність яких (як дає можливість побачити квазі-трансцендентальна оптика Дерида) може сягати порядку граничної гетерогенності. Відповідно, переважання будьякого 3 полюсів руйнує властиву трансцендентальній настанові засадничу апоретичність [2, с. 130] i, водночас, девальвує проект трансцендентальної універсальності як такої, що грунтується на відношенні між відмінними (гетерогенними) доменами [3]. Отже, 3 метою збереження кожного з таких полюсів у їхній своєрідності, видається доцільним говорити не про необ'єктність, а про квазіоб'єктність (квазі-предметність) [42]. Авто-референтне відношення за певних необхідних обмежень все ж даватиме можливість в окремих випадках говорити в модусі квазі або als ob про об'єктність еgо (свідомості) у межах авто-референтного відношення [43; 44].

Загалом підхід Анрі можна віднести до поширених у трансцендентальному і навколо-трансцендентальному колі спроб позбавити кантівську, а згодом і гусерлівську концепцію певних «не співмірностей» і нерозв'язностей - апорій, наявність і тип яких значною мірою становлять специфіку трансцендентального мислення.

Повертаючись безпосередньо до картезіанської проблематики, хотілося б зазначити, що примирити трансцендентальну потребу в екстеріорному іншому (що має два основні модуси втілення: об'єкт та інфінітне [45]) - поза яким не є можливим жоден досвід і який має бути присутнім у кожному акті мислення, судження, рефлексії [46] - i, знов таки, трансцендентальну вимогу радикальної асубстанційності (функціональності) для трансцендентального суб'єкта (свідомості, еgo) [47] видається можливим на грунті тлумачення картезіанського «cogito, sum» крізь призму автореферентності. Понад це, певною мірою навіть можна сказати, що доречність чи, навпаки, іррелевантність критики уречевлення 
cogito Декартом залежатиме від того, тлумачимо ми його як автоафекційну чи як авто-референтну структуру [48].

До картезіанського дискурсу авто-референтність найбільш очевидним чином входить саме у вигляді авто-афектації. Порівнюючи підходи Марйона і Анрі, Руд Вельтен відзначає більший радикалізм останнього: тоді як Марйон обмежується припущенням, що картезіанське еgо постає в модусі авто-афектації в певних випадках, Анрі вважає cogito цілком і повністю не-інтенційним і розглядає авто-афекційність як «загальну феноменологічну структуру cogito» [22, с. 297; 49].

Марйон грунтує свій виклад концепції авто-афекційності соgito на інтерпретації підходу Анрі: не просто його власного підходу, але на інтерпретації Декарта, здійсненій Анрі в річищі проблематики авто-афекційності як граничної іманентності [50]. Покликаючись на твердження Анрі про те, що картезіанство є феноменологією [19, с. 105] (суть якого він поділяє, що підтверджує його власний декартознавчий шлях), Марйон означує мету свого дослідження як випробовування можливості підходу до cogito, ergo sum в дусі Анрі - тобто, такого підходу, що, грунтуючись на ідеї автоафекційності свідомості, уникав би інтенційності і, отже, підпадання під пов'язані з нею апорії [19, с. 105; 51]. Постановка під питання не авто-афекційного тлумачення cogito (тобто тлумачення, яке можна було б визначити, навпаки, як авто-референтне) вмотивовується Марйоном, зокрема, за допомогою такого аргументу, що редуковане до об'єктивності Я (тобто, Я як будь-який інший феномен) отримує зумовлене існування i, отже - згідно з картезіанською системою координат - $\epsilon$ недостовірним. Таким чином, об'єктивація Я підважує його статус Першопочатку - статус, завдяки якому, власне, Я виявляється спроможним до репрезентації об'єктивності [19, с. 103; 52]. Сенс проблеми вбачається Марйоном У зумовленому інтенційністю і рерпрезентаційністю розриві між мисленням і мислимим (ноезою і ноемою), які ніколи не зможуть бути з'єднані - навіть у такому специфічному випадку, коли вони означуються за допомогою одного й того самого терміну [19, с. 103]. Марйон надає проблемам, що виникають за умови інтерпретації cogito, ergo sum на засадах принципів інтенційності й 
репрезентації, статус апорій [19, с. 103] i, у підсумку зазначає, що вони могли б отримати розв'язання за допомогою авто-афектації, з iii безпосередністю [19, с. 117]. Але чи повинні ці апорії бути подолані? Чи не втрачається за умови їхнього розв'язання певна своєрідність Декартової думки, яка, власне, не останньою чергою зумовлює можливість віднесення картезіанської філософії до трансцендентальної парадигми філософського мислення?

Висновок про апорії, що виникають на грунті інтенційності й репрезентативності за умови, якщо останні привносяться чи віднаходяться в структурі cogito, формулюється Марйоном наприкінці викладення так би мовити «контр-сюжету» (щодо сюжету, присвяченого авто-афекційності за Анрі), темою якого є трансцендентальний ракурс бачення філософії Декарта. I хоча преференції Марйона, здавалося б, знаходяться на боці підходу Анрі (про це свідчать кінцеві положення розділу «Картезіанських питань», присвяченого аналізу анрієвської концепції), певні тези і проміжні висновки, що 3'являються протягом дослідження Гусерлевої і Кантової рецепцій Картезієвого ego cogito, ergo sum - зокрема і особливо в тих моментах, де вони стосуються тематики іншого - виказують й інший полюс Марйонової прихильності. Адже зумовленість cogito радикально Іншим є центральною темою феноменологічного картезіанства Марйона. Зокрема, на цьому моменті грунтується його концепція радикальної даності, виходячи з інтересів якої, між іншим, і захищається неінтенційний (й нерепрезентаційний) підхід. Але зворотна, «інша» інтенційність не означає відсутності останньої; а спроби поєднання концепцій екстеріорного Іншого (інфінітного) і радикальної іманентності авто-афекційності призводитимуть до не меншої апоретичності, ніж та, що викривається Марйоном за допомогою філософії Анрі у межах інтенційнорепрезентаціоналістського підходу [53].

У межах цієї другої лінії розгляду проблеми cogito, яку умовно можна визначити як гусерліанську, віднаходяться моменти авто-референтності еgo - на противагу аспектам авто-афекційності, що артикулюються за умови прийняття Анрієвого підходу. На початку викладу Марйон зазначає, що, згідно з Гусерлевою позицією, cogitatum від самого початку постає включеним до царини cogitatio; остання, своєю чергою, не мала б ні значення, ні об'єкта, 
ні навіть власної можливості, якби була позбавлена cogitatum'у [19, с. 97]. Ця думка ілюструє й розкриває важливий аспект гусерлівської критики Декарта, що полягає у звинуваченні останнього у так би мовити «редукції» ego до чистого cogito - поза цариною розмаїття cogitationes, що цьому cogito належать, а це означає, поза корелятивним розмаїттям cogitatum'ів, яким ці cogitationes відповідають.

Далі Марйон говорить про певний «зсув», за допомогою якого «я мислю» віддаляється від Я в напрямку об'єкта, позиціонованого в якості об'єкта цим самим Я (саме на таких засадах виявляється зазначений вище зв'язок між інтенційністю й репрезентацією). Cogito, каже Майон, включає своє необхідно інше - cogitatum - всередину себе, будучи посутньо структурованим інтенційністю [19, с. 97]. Така модель мислиться феноменологією навіть не просто взірцевою, але універсальною для функціонування cogito (свідомісті, Я, суб'єктивності). У такому разі даній моделі підпорядковуватиметься і особливий, винятковий випадок (у певному сенсі можна визначити його як гіперболічний) думки, що мислить саму себе $[19$, с. 98; 54]: тобто, коли має місце певна квазі-ідентичність cogito i cogitatum'y. У цьому разі відношення між ними $є$ автореферентним. Тоді, згідно 3 поясненням Марйоном гусерлівської позиції, свідомість - як інтенційна й така, що завжди має свій об'єкт (об'єкти) - схоплює себе саму за допомогою такого роду інтенційності, що є подвоєною й загорнутою на себе [19, с. 98; 55].

Як наслідок, апорії, про які говорить Марйон, впираються у проблему трансцендентальної «деконструкції» тотожності еgо: адже те, чого у вигляді сущого, що існує, сягає ego cogito, з необхідністю виявляється іншим щодо нього як таке, що, по суті, дорівнює об'єкту (який хоча і $є$ само-репрезентованим, все ж $є$ об'єктивізованим за допомогою репрезентації) [19, с. 103]. Цей об’єкт втрачає тотожність 3 «ego - cogito, ergo est» [19, с. 103]: тотожність, яку Анрі намагається врятувати шляхом зсуву до автоафекційності. У загальному підсумку запропонований ним шлях виявляється анти-трансцендентальним [56] через апелювання до іманентності і редукцію факторів відношення й відмінності, а разом $з$ тим - іншості, межі, екстеріорності і т.д. 
Зрештою, Марйон, здається, прагне узгодити два «гетерогенні» підходи. 3 одного боку, він припускає інтенційну парадигму тлумачення ego cogito - але в такому модусі, що саме воно дозволяє інтенційність (у трансцендентальних термінах - постає умовою можливості інтенційності), а не, навпаки, інтенційність є умовою можливості cogito (свідомості) [19, с. 105; 57]. 3 іншого боку, таке припущення (або припускання) вмотивовує розбудову «радикальнішої» феноменології [19, с. 105], яка, власне, робить інтенційну феноменологію можливою. Тобто, в парадоксальний спосіб, інтенційна концепція cogito є чинником, який легітимуватиме перехід на рейки неінтенційної (іманенетистської) концепції, що грунтується на принципі авто-афектації [58]. І проект такої радикальної феноменології саме і являє собою концепція Анрі.

Попри безперечну значущість такої універсалізації (внаслідок перекривання двох інтерпретаційних трендів) для осмислення i розвитку трансцендентально-феноменологічного дискурсу в цілому, мені все ж здається, що в певному сенсі цей хід марйонівської думки є свідченням повернення в річище «догматичної» метафізики, засади якої ставляться під питання не лише в трансцендентальних проектах Канта, Гусерля і Дерида, але вже в межах самої картезіанської філософії (і Марйон, власне, є одним із провідних мислителів, які відкривають нам Декарта як майже трансцендентального - «прото-трасцендентального» філософа!) Адже пошук граничної, до-інтенційної феноменології - пошук, який веде до граничної іманентності як «розв'язання» проблеми трансцендентальної апоретичності, - $\epsilon$ тим самим пошуком першопочатку, якому трансцендентальне мислення протиставляє пошук умов можливості. Цей «метафізичний» («догматичний», «логоценстристський») початок має бути унарним і простим: до таких вимог de facto впритул наближається авто-афекційна суб'єктивність. Натомість інтенційність завжди передбачає відношення, відмінність, іншість, Іншого і унеможливлює редукцію до Одного. Спрямованість на інше трансцендентально-феноменологічної «свідомості про...», а також пов'язаний з чинником інтенційності принцип кореляції постають граничними засадами (як методологічними, так і онтологічними), що не підлягають подальшому спрощенню. 
Результати проведеного дослідження можна підсумувати у вигляді наступних висновків.

У ході феноменологічних тлумачень картезіанської концепції cogito виявляється питання про співвідношення між принципами авто-референтності і авто-афекційності, що має непересічну значущість для трансцендентального дискурсу в цілому. Принцип авто-референтності виявляється релевантним трансцендентальним вимогам, оскільки поєднує моменти ідентичності й відмінності, конституюючи свого роду «інакшість als ob».

Утім, авто-референтністю передбачається і розщеплення картезіанського суб'єкта, що є підставою для критики концепції Декарта його трансцендентально-феноменологічними послідовниками: авто-референтність постає як фактор, що зумовлює й уможливлює субстантивацію cogito. Натомість авто-афекційність, з іiї чистою функціональністю і відсутністю предметної «фази», здавалося б, ідеально відповідає трансценденталістським домаганням асубстанційності свідомості, запобігаючи ії реїзації.

Тлумачення ego cogito в аспекті авто-афекційності як іманентної суб'єктивності (тобто, граничної необ'єктивованості), а також елімінація інтенційності з метою абсолютизації акту (Анрі) видаються моментами радикалізації Гусерлевої критичної інтерпретації Декарта. Утім, редукція інтенційності - i, отже, будь-якої об'єктності - загрожує розривом із засадничим трансцендентальним принципом відношення-відмінності і втратою стосунку до іншого, що лежить в основі трансцендентально-феноменологічного мислення. Натомість наявна в авто-референтному відношенні квазі-об’єктність («об'єктність als ob») уможливлює збереження значливих для трансцендентального дискурсу предикатів відмінності, гетерогенності, екстеріорності і т.п.

На грунті тлумачення картезіанського «cogito, sum» крізь призму авто-референтності видається можливим узгодити властиве трансцендентальному мисленню спрямування на інще, що є умовою можливості трансцендентально-феноменологічного досвідчування та, отже, будь-якого акту свідомості (як свідомості про...), і принципову асубстанційність, функціональність трансценденталь- 
ного суб’єкта або свідомості, що є відмітною рисою: точніше - фундаментальною вимогою трансцендентальної філософії.

\section{ЛІТЕРАТУРА ТА ПРИМІТКИ}

1. Ільїна А. Декарт sub specie transcendentalis: кантіанська і феноменологічна ретроспективи. Аó $\xi \alpha$. Докса. Збірник наукових пращь з філософії та філологї̈. Вип. 1, № 33. Сміх як інтелектуальна розвідка: семантика та герменевтика смішного. Одеса : Акваторія, 2020. С. 20-49.

2. Ільїна А. Деконструкційний поворот у трансцендентальному мисленні. Sententiae. 2015. Vol. 33, № 2. C. 125-148.

3. Ільїна, А. Дерида як об'єкт історії філософії: концепт апорії в ракурсі проблеми універсальності. Sententiae. 2019. Vol. 38, № 1. С. 6-26.

4. Лактіонова А. «Cogito ergo sum» і філософія діï. Sententiae. 2015. Vol. 32, № 1. C. 88-99.

5. Balibar E. «Ego sum, ego existo»: Descartes au point d'heresie. Balibar E. Citoyen sujet et autres essais d'anthropologie philosophique. Paris : PUF, 2011. P. 87-120.

6. Balibar É. Kant, critique du «paralogisme» de Descartes. Le «je pense» (Ich denke) comme sujet et comme substance. Intellectica. Revue de l'Association pour la Recherche Cognitive. 2012. № 57: Les lieux de l'esprit. P. 21-33.

7. Boos W. A Self-Referential 'Cogito'. Philosophical Studies: An International Journal for Philosophy in the Analytic Tradition. 1983. Vol. 44, № 2. P. 269-290.

8. Brinkmann K. Hegel sur le cogito cartésien. Actes du colloque international Descartes. 1997. Vol. 52, № 3. P. 639-652.

9. Derrida J. The Animal That Therefore I Am / trans.: Wills D. New York : Fordham University Press, 2008. 176 p.

10. Descartes R. Meditationes de prima philosophia. R. Descartes. OEuvres complètes, in 11vol. / ed. Ch. Adam, P. Tannery. T. VII: Meditationes de prima philosophia, Obiectiones, Responsio, Epistola ad Dinet. Paris : Vrin, 1996. P. 3-90.

11. Hart J. G. Intentionality, Phenomenality, and Light. Selfawareness, Temporality, and Alterity. Central Topics in Phenomenology / ed. Zahavi D. Dordrecht : Springer Science+Business Media. 1998. P. 59-82.

12. Henry M. L'essence de la manifestation. Paris : Presses Universitaires de France, 1963. 911 p.

13. Henry M. La Barbarie. Paris: Presses Universitaires de France, Quadrige 2011. 203 p. 
14. Hetherington S. The Cogito: Indubitability without Knowledge? Principia: An International Journal of Epistemology. 2009. Vol. 13, № 1. P. 85-92.

15. Hintikka J. «Cogito, ergo sum as an inference and a performa»ce». Philosophical Review. 1963. Vol. 72, № 4. P. 487-496.

16. Janicaud D. et al. Phenomenology and the «Theological Turn»: The French Debate / trans.: B. G. Prusak, J. L. Kosky. New York : Fordham University Press, 2000. 245 p.

17. Kant I. Critique of Pure Reason / trans.: P. Guyer, A. Wood. Cambridge : Cambridge University Press, 1998. 512 p.

18. Lawlor L. Jacques Derrida. The Stanford Encyclopedia of Philosophy (Fall 2019 Edition) / Ed. E. N. Zalta. URL=https://plato.stanford.edu/archives/fall2019/entries/derrida/

19. Marion J.-L. Does the Cogito Affect Itself? Generosity and Phenomenology: Remarks on Michel Henry's Interpretation of the Cartesian Cogito. J.-L. Marion, Cartesian Questions: Method and Metaphysics / trans.: D. Garber. Chicago: The University of Chicago Press, 1999. P. 96-117.

20. Mehl E. Auto-affection et cogito. Sur le cartésianisme de Michel Henry. Emotional Minds. The passions and the limits of pure inquiry in early modern philosophy / Ed. S. Ebbersmeyer. Berlin: de Gruyter, 2012. P. 31-50.

21. Morin E. Computo, ergo sum. Chimères. 1990. N 8. P. 1-20. URL=https://www.persee.fr/doc/chime_0986-6035_1990_num_8_1_1161:6

22. Savatovsky D. Le cogito est-il un énoncé performatif? Langages. 1985. № 77. P. 55-73.

23. Staudigl M. From the "metaphysics of the individual" to the critique of society: on the practical significance of Michel Henry's phenomenology of life. Continental Philosophy Review. 2012. Vol. 45, № 3. P. 339-361.

24. Welten, R. L’âme cartésienne de la phénoménologie. Phenomen,logy, Volume 4: Selected Essays from Northern Europe, Traditions, Trans?tions and Challenges / Ed. D. Moran, H. R. Sepp. Zeta Books, 2010. P. 275303.

25. Williams F., Kirkpatrick R. Translators' introduction. J.-P. Sartre, The Transcendence of the Ego / trans.: F. Williams, R. Kirkpatrick. New York : Hill and Wang. 1060. P. 11-27.

26. Zahavi D. Subjectivity and Immanence in Michel Henry. Subjectivity and transcendence / Ed. Grøn, A., Damgaard, I., Overgaard, S. Tübingen : Mohr Siebeck, 2007. P. 133-147.

27. Поняття авто-референції і ретро-референції є близькими, але не тотожними. Утім, завдання даної праці не потребують експлікації їхнього розрізнення, тому тут ми розглядаємо їх як синоніми. 
28. Дана стаття висвітлює окремі проблеми загального дослідження трансцендентальних засновків Декартової філософії. Основну концептуальну частину нашого підходу викладено у статті [1].

29. «Уважне читання тексту показує, що... Кантів довід повністю базується... на тому, що свідомість є безпосередньо самосвідомістю.., і що ця свідомість відноситься до себе або визнає себе як суб'єкта думок. Авто-референтність, отже, є не помилкою, а внутрішньою властивістю суб'єкта» [6, с. 24].

30. Ця проблема $є$ предметом самостійного дослідження. Проблема, власне, полягає в тому, що «мінімум об'єктності» є необхідною умовою для здійснення операції авто-референтності. Утім, на нашу думку, питання полягає у ступені умовності такої об'єктивації (за умови дотримання такої властиво трансцендентальної умовності не відбуватиметься приписування за означенням функціональній свідомості - про автореферентність якої і йдеться - предикату існування і статусу «речі світу»).

31. У межах цієї критики, викладеної у праці «Голос і феномен», Дерида формулює відому тезу про «слухання (почутість)-себе-таким-щоговорить», котра $є$ вираженням притаманної гусерлівській феноменології авто-афекційності абсолютно своєрідного типу.

32. До речі, не останньою чергою така деконструкція іманентності уможливлює саму ідею трансцендентальної свідомості.

33. Причому перформативність постає характеристикою як формули «cogito ergo sum» [4; 15], так і самого cogito [21].

34. Збіг функціонуваня i тематизації - властивість автореферентних структур, зокрема перформативів.

35. І яка не властива авто-афектації (як такій, що належить полю іманентності): про це йтиметься нижче.

36. Цікаво відзначити, що Сартрова гіперболізація значущості властивості інтенційності для феноменологічної свідомості (Роберт Кіркпатрік і Форест Вільямс навіть зауважують, що «тоді як для Гусерля інтенційність є однією із суттєвих рисою будь-якої свідомості, для Сартра інтенційність $\epsilon$ свідомістю» [25, с. 22]) має ті самі функцію, засади і наслідки, які неінтенційність суб'єктивності має для Анрі. В обох випадках йдеться про абсолютну простоту, прото-дистинктивність і своєрідність радикальну інакшість суб'єктивності до і поза всяким об'єктом (об’єктністю). Утім, як уведення квазі-об'єктності, так і їі критичне обмеження видаються нам необхідними універсальними вимогами для феноменологічного мислення як різновиду трансцендентального дискурсу до того ж як однієї із взірцевих версій трансценденталізму. 
37. Утім, наприклад, у Дерида знаходимо чітку дистинкцію двох принципів. Визначаючи як авто-референтну структуру кантівське «я мислю» - яке $\epsilon$ концептуальним «нащадком» картезіанського cogito - Дерида зазначає, що, згідно із загальною думкою, цього я мислю, що вирізняє людський розум, бракує тварині, котра, втім, поза сумнівом наділена здатністю авто-афектації. При цьому авто-референтність він визначає як само-дистанціювання, що надає їй властиво деконструкційні риси (не зважаючи на те, що в даному випадку авто-референтність постає радше об'єктом деконструкційної критики) [9, с. 94].

38. Адже найпростішим чином авто-референтність визначається наступним чином: ситуація, коли дещо стає власним об'єктом.

39. Таким чином, радикальність феноменологічного підходу Анрі спрямована, зокрема, на гіперболічне дотримання трансцендентальнофеноменологічних трендів 1) «неподвоєння світу» і 2) десубстантивації свідомості.

40. Знов-таки, в цьому пасажі виявляється гіперболічне прагнення Анрі до трансцендентально-феноменологічної «деконструкції» метафізичного подвоєння: але йдеться не про редукцію субстанційності, а про іiі ототожнення, або, краще сказати, іманентизацію царині феноменального.

41. Як резюмує сутність підходу Анрі Дан Захаві, «Анрі наполягає, що оригінальна самоманіфестація суб'єктивності виключає всі види розриву, відділення, іншості, відмінності, екстеріорності і опозиції. ... Також вона не передбачає жодного відношення, оскільки реляційність не має місця в радикальній іманентності, іманентності, такою мірою насиченою само маніфестацією, що вона виключає свого роду бракування, яке 3 необхідністю супроводжувало б будь-який розрив чи внутрішню дистанцію» [26, с. 137]. Міхаель Штаудігль, вдало підсумовуючи як засади трансцендентально-феноменологічної думки, так і (тим самим) аспекти Анрієвої критики класичної феноменології, зазначає, що «Для Анрі вирішальна пресупозиція класичної феноменології... полягає у тому, що життя свідомості має здійснюватися в горизонті екстеріорності... в домені живої суб'єктивності, що інтенційно перевершує себе. Саме через інтеційність у цій екстеріорності суб'єкт не збігається із самим собою тією мірою, якою він завжди відрізняється від себе... 3 погляду Анрі, Гусерль першим розважав над цим розумінням інтенційності, яке було радикалізоване постгусерлівською феноменологією і вплинуло також на деконструкцію» [23, c. 342].

42. Особливо якщо під об'єктом або предметом розумітимемо все, що може стати «темою» у феноменологічному сенсі. 
43. Відмова від інтенційності пов'язана з відмовою також від репрезентаційності, що (в кантівськму значенні поняття рерпезентаціі) $\epsilon$ осердям трансцендентальної думки 3 огляду на своє положення «середньої ланки» між тим, що мислить і мислимим; у феноменологічних термінах - між ноезою і поемою (про синхронність заперечення інтенційності і репрезентаційності див.: [19]).

44. Така квазі-об'єктність виявляється, зокрема, в тому, що феноменологічне досвідчування передбачає в тому числі (якщо не першою чергою) тематизацію свідомістю власних актів. Межами такої квазіоб'єктивації постають потік часу-свідомості, з одного боку, і Я як центр ідентичності - 3 іншого; функціональне cogito - взяте поза своїми cogitationes - також може бути віднесене до нетематичного, принципово необ'єктного виміру.

45. Потрібно уточнити, що ці модуси не є взаємовиключними, але радше позначають як певні ракурси тлумачення іншості як екстеріорностi.

46. Так, застосування принципу differance до проблеми самосвідомості демонструє, що авто-афектація завжди по суті виявляється гетеро-афектацією: таким є висновок деридианської критики Гусерлевої феноменології в «Голосі й феномені».

47. На нашу думку, найбільш несуперечливим втіленням такого поєднання є феноменологічний концепт інтенційності: $з$ одного боку, свідомість принципово є свідомістю про інше (ми не розглядатимемо тут специфічні випадки неінтенійної свідомості), а з іншого - саме ця функція інтенційності і надає свідомості такої своєрідності, що не припускає іiі об'єктивацію й уречевлення. Але саме інтенційність феноменологічної свідомості є предметом критики Анрі, почасти підтриманої Марйоном, на противагу якій він уводить своє поняття іманентної авто-афекційності (або авто-афектаціі).

48. Залишимо за лаштунками більш відоме розрізнення між тлумаченнями cogito, ergo sum як висновку чи як перформативу: розрізнення, яке частково збігається із зазначеним вище, адже оскільки автореферентність передбачає квазі-об'єктивацію, то іiі можливим наслідком може стати те саме, що і висновування від акту cogito до речі або субстанції. В обох випадках йдеться про імплікації переходу (з феноменологічного погляду нелегітимного) від свідомості до світу, а саме - світу поза феноменологічною редукцією.

49. Потрібно уточнити, що і Анрі, і Марйон обговорюють автоафекційність ego (cogito), розглянутого в тому числі - якщо не здебільшого - в модусі душі: який Гусерль розглядає як метафізичний залишок у 
Декартовій концепції, що обмежує і перешкоджає розвиткові феноменологічного «начала» картезіанської філософії.

50. Концепція авто-афекційності Мішеля Анрі базується на критиці інтенційності й репрезентаційності, які є невід'ємними характеристиками трансцендентальної суб'єктивності в трансценденталізмі КантовоГусерлевого зразка.

51. За словами самого Анрі, «афекційність форми, маніфестована в cogito, тобто, в царині чистого мислення, і саме як афекційність цього мислення, $є$ в суттєвий спосіб визнаною Декартом - і водночас ним заперечена» [12, с. 642-643].

52. Утім, в іншому місці Марйон дає підстави саме для автореферентого підходу, коли пише, що cogito, ergo sum як звернена на себе думка стає існуванням, оскільки стає принципом [19, с. 112] (звернімо увагу, що в цій майонівській тезі імплікується зумовлювання онтологічного виміру цариною мислення і пізнання: таку інверсія ординарного для традиційної метафізики порядку можна розглядати як важливу ознаку трансценденталізації філософії в картезіанському дискурсі).

53. Питання необхідності чи довільності зв'язку між інтенційністю і репрезентаційностю $є$ темою окремих досліджень: утім, хотілося б вказати на проблематичність і неочевидність цього питання і, відповідно, поставити під сумнів самозрозумілість такого пов'язання в Марйоновому дискурсі.

54. Як зауважує Марйон, Гусерль і на цей специфічний модус думки накладає структуру інтенційності [19, с. 98].

55. Зауважимо, що структура зворотності є важливою і наскрізною для трансцендентально-феноменологічного мислення в цілому.

56. Що не заперечує трансцендентальної значливості багатьох окремих аспектів його концепції, деякі з яких було виявлено й підкреслено в попередньому фрагменті цієї розвідки.

57. Якщо трансцендентально-феноменологічний погляд зумовлює підпорядкування ego cogito універсальному принципу інтенційності, то, згідно з тезою Марйона, на яку ми тут посилаємося, навпаки, ego cogito $€$ універсальнішим принципом і зумовлює в тому числі принцип інтенційності.

58. Загалом цей гіперболічний жест - крок до феноменології, так би мовити, вищого порядку - можна пов'язати зі зсувом від методологічного виміру (у межах якого, насамперед, $є$ чинним принцип інтенційності) до онтологічного, що є притаманним пізній французькій феноменологiï. 


\section{REFERENCES}

Balibar, E. (2011). «Ego sum, ego existo»: Descartes au point d'heresie. In: E. Balibar. Citoyen sujet et autres essais d'anthropologie philosophique (pp. 87120). Paris: PUF.: 102-103

Balibar, É. (2012). Kant, critique du «paralogisme » de Descartes. Le « je pense " (Ich denke) comme sujet et comme substance. Intellectica. Revue de l'Association pour la Recherche Cognitive, 57(1): Les lieux de l'esprit, 21-33.

Boos, W. (1983). A Self-Referential 'Cogito'. Philosophical Studies: An International Journal for Philosophy in the Analytic Tradition, 44(2), 269-290.

Brinkmann, K. 1997. Hegel sur le cogito cartésien. In: Actes du colloque international Descartes, 52(3), 639-652.

Derrida, J. (2008). The Animal That Therefore I Am (D. Wills, Trans). New York: Fordham University Press, 176 p.: 94

Descartes, R. (1996). Meditationes de prima philosophia. In: R. Descartes, OEuvres complètes, in 11vol. (Ch. Adam, \& P. Tannery, Eds.). T. VII: Meditationes de prima philosophia, Obiectiones, Responsio, Epistola ad Dinet (pp. 390). Paris: Vrin.

Hart, J.G. (1998). Intentionality, Phenomenality, and Light. In: D. Zahavi (Ed.). Self-awareness, Temporality, and Alterity. Central Topics in Phenomenology (pp. 59-82). Dordrecht: Springer Science+Business Media.: 81

Henry, M. (1963). L'essence de la manifestation. Paris: Presses Universitaires de France, 911 p.: 261

Henry, M. (2001). La Barbarie. Paris: Puf - Quadrige.

Hetherington, S. (2009). The Cogito: Indubitability without Knowledge? Principia: An International Journal of Epistemology, 13(1), 85-92.

Hintikka, J. (1963). Cogito, ergo sum as an inference and a performance. Philosophical Review, 72, (4), 487-496.

Ilyina, A. (2015). Deconstructive Turn in Transcendental Thinking. Sententiae, 33(2), 125-148. [In Ukrainian].

Ilyina, A. (2019). Derrida as an object of the history of philosophy: the concept of aporia in terms of the universality problem. Sententiae, 38(1), 6-26. [In Ukrainian]. 
Ilyina, A. (2020). Descartes sub specie transcendentalis: Kantian and Phenomenological Retrospectives. $\Delta$ ó $\xi \alpha$ / Doxa. Zbirnyk naukovyh prac' z filosofii ta filologii, 1(33), 20-49. [In Ukrainian].

Janicaud, D. et al. (2000). Phenomenology and the «Theological Turn»: The French Debate (B. G. Prusak, J. L. Kosky, Trans.). New York: Fordham University Press, $245 \mathrm{p}$.

Kant, I. (1998). Critique of Pure Reason (P. Guyer, A. Wood, Trans:). Cambridge: Cambridge University Press, 512 p.

Laktionova, A. (2015). «Cogito ergo sum» I filosofija dii [«Cogito Ergo Sum» and Philosophy of Action]. Sententiae, 32(1), 88-99.

Lawlor, L. (2019). Jacques Derrida. In: The Stanford Encyclopedia of Philosophy (Fall 2019 Edition), E. N. Zalta (ed.). Retrieved from https://plato.stanford.edu/archives/fall2019/entries/derrida

Marion, J.-L. (1999). Does the Cogito Affect Itself? Generosity and Phenomenology: Remarks on Michel Henry's Interpretation of the Cartesian Cogito. In: Marion, Jean-Luc Cartesian Questions: Method and Metaphysics. (D.Garber, Trans.) (pp. 96-117). Chicago: The University of Chicago Press.

Mehl, E. (2012). Auto-affection et cogito. Sur le cartésianisme de Michel Henry. In: S. Ebbersmeyer (Ed.). Emotional Minds. The passions and the limits of pure inquiry in early modern philosophy (pp. 31-50). Berlin: de Gruyter: 32

Morin, E. (1990). Computo, ergo sum. Chimères, $N^{\circ}$ 8, 1-20. Retrieved from https://www.persee.fr/doc/chime_0986-6035_1990_num_8_1_1161: 6

Savatovsky, D. (1985). Le cogito est-il un énoncé performatif? Langages, 77, 55-73.

Staudigl, M. (2012). From the "metaphysics of the individual"' to the critique of society: on the practical significance of Michel Henry's phenomenology of life. Continental Philosophy Review, 45(3), 339-361.

Welten, R. (2010). L’âme cartésienne de la phénoménologie. In: Moran, D., Sepp, H. R. (Eds.). Phenomenology,Volume 4: Selected Essays from Northern Europe, Traditions, Transitions and Challenges (pp. 275-303). Zeta Books.

Williams, F., Kirkpatrick, R. (1960). Translators' introduction. In: .J.-P. Sartre, The Transcendence of the Ego (F. Williams, R. Kirkpatrick, Trans.) (pp. 1127). New York: Hill and Wang. 
Zahavi, D. (2007). Subjectivity and Immanence in Michel Henry. In: Grøn, A., Damgaard, I., Overgaard, S. (eds.), Subjectivity and transcendence (pp. 133147). Tübingen: Mohr Siebeck.

\title{
Anna Ilyina
}

Candidate in Art criticism (Ph.D.), Doctoral candidate, H. Skovoroda Institute of Philosophy of the NAS of Ukraine; Kyiv, Ukraine; e-mail: husserliana2016@ukr.net; ORCID: http://orcid.org/0000-0003-4921-5777

\section{Auto-referentiality and Auto-affectivity as Competing Patterns of Reading of Descartes's Cogito Conception: Transcendental-phenomenological Context}

\begin{abstract}
The paper examines two alternative possibilities to interpret Cartesian Cogito conception: as auto-referential structure and as auto-affectivity. A context of analysis is transcendental-phenomenological view on Cartesian philosophy as on the origin of transcendental motive. A role of auto-referentiality principle in transcendental thinking is determined. In terms of transcendental discursive field the principles of auto- referentiality and auto-affectivity are compared. By investigation of perspectives offered by Henry and Marion on interpretation strategies as regards Cartesian approach, some moments of irrelevance of auto-affectional attitude to transcendental thinking criteria are brought to light. By contrast, an adequacy of auto-referential model to the transcendental framework is justified. The author concludes that in spite of seeming priority in the realm of transcendental discourse of auto-affection, stemming from peculiar to its essence radicalization of functional aspect of consciousness and elimination of risk of Cogito's substantivation, implied for its part in the structure of auto-referentiality, the last is more suitable for the claims of transcendental thinking because of retaining of «relation-difference» principle, constitutive for transcendental thought - which in a context of auto-affection turns out to be taken down. In sum, albeit the fact that both the treatment of ego cogito as immanent subjectivity and absolutization of consciousness' act importance (peculiar to conception of cogito as auto-affection) seem to be the moments of hyperbolization of Husserl's critical interpretation of Descartes by Henry and Marion, nevertheless reduction of intentionality and of any objectness whatever, following from this aspects of auto-affectivity, threatens with loss of con-
\end{abstract}


cern to other, which underlies transcendental-phenomenological thinking. Instead, some quasi-objectivity inherent to auto-reference ("objectivity als ob") allows save such significant to transcendental discourse predicates as heterogeneity, exteriority, distinctiveness etc.

Keywords: auto-referentiality, auto-affectivity, Cogito, phenomenology, otherness. 